\title{
On (Not) Reading Wales in W. G. Sebald's Austerlitz (2001)
}

Mererid Puw Davies, University College London

This article explores representations of Wales in W. G. Sebald's novel Austerlitz (2001). It considers why the novel's passages on Wales have often evaded scholarship on Sebald's writing to date, and ways in which Austerlitz may seem eccentric to Welsh critical canons too. The article places Austerlitz in intertextual relationships with the literatures and cultural history of Wales and so uncovers some of the novel's hidden Welsh references. In alluding to Evan Morgan, $2^{\text {nd }}$ Viscount Tredegar for example, Austerlitz simultaneously turns away from Welsh history and reveals it in unexpected ways. The novella also calls to mind the nineteenthcentury preacher John Elias in a way which offers an unusual perspective on Sebald's poetics of coincidence. The article suggests alternative critical contexts in which Sebald's Wales becomes productively legible; put most globally, it is interested in the practice and rewards of non-metropolitan reading, relationships between the supposed centres and margins of literature and the ways in which they remain in perpetual (re-)negotiation.

Keywords: Sebald, Austerlitz, Wales, Welsh, Gothic, Evan Morgan, John Elias, intertextuality, birds, names, uncanny, coincidence, reservoirs, non-metropolitan, Tryweryn, Vyrnwy 


\section{Introduction}

The last of W. G. Sebald's (1944-2001) major works to be published during his lifetime was the long literary prose work Austerlitz (2001), in which a first-person narrator reports what the eponymous protagonist tells him of his life, in conversations spanning decades. ${ }^{1}$ Jacques Austerlitz came to Britain from Nazi-occupied Prague on a Kindertransport in 1939, aged fourand-a-half. His foster family erases his origins and it is only in middle age, in increasing psychological pain, that he seeks his forgotten history. Austerlitz follows clues of memory, intuition, suggestion and deduction to Prague. There, he learns that while nothing is certain about the fates of his parents, Agáta Austerlitzová and Maximilan Aychenwald, it seems almost inevitable that, both Jews, they were murdered during the Holocaust. At the end of the novel, his enquiry into his past continues.

The novel invokes localities from South America to Russia, and is set, inter alia, in Belgium, London, Paris, Marienbad, Terezín and Prague. ${ }^{2}$ One important section is located in North Wales, where Austerlitz lives as a child in what he calls 'einer Art von Gefangenschaft' (p. 70) at the small, rural lakeside town Bala. English and Welsh replace Jacques's mother tongues Czech and French and he is re-named Dafydd Elias by his otherwise childless foster parents, Gwendolyn Elias and her husband Emyr, a Calvinist Methodist minister. Austerlitz

I am grateful all at the colloquium 'Dialog. Cymru a'r Almaen' at the College of Arts and Humanities, Prifysgol Bangor, 22 October 2016 for the opportunity to discuss some thoughts in this article, and their valuable suggestions. I thank the editors of $O$ 'r Pedwar Gwynt for a forum to reflect in print on Austerlitz and Wales, and Heini Gruffudd for his response.

${ }^{1}$ W. G. Sebald, Austerlitz (2001) (Frankfurt am Main: Fischer, 2008). Further references follow in the text.

${ }^{2}$ Spellings of place names follow those in Austerlitz, except where a familiar English form is available, as e.g. with Prague. Austerlitz refers to Welsh places by English names: this article follows suit with regard to those locations as they feature in the novel, in order to identify them as literary citations rather than real places. Otherwise, place names in Wales are in Welsh, followed by English in parenthesis where it differs. 
later learns his real name at boarding school and soon abandons Dafydd Elias, along with other vestiges of his Bala childhood like the Welsh language. Following Gwendolyn's and Emyr's deaths in 1947 and 1954 respectively, Austerlitz lives in Oxford, Paris and London, never returning to Wales except to visit his schoolfriend Gerald Fitzpatrick's family home, a dilapidated yet wonderful mansion, Andromeda Lodge, on the Mawddach estuary. The last of these journeys is in 1957, to the double burial at nearby Cutiau of Gerald's uncle Evelyn and great-uncle Alphonso. Andromeda Lodge is sold, and in 1966 Gerald dies in a flying accident, severing Austerlitz's final, distant Welsh tie. Here, what might appear to be the novel's main narrative, of Austerlitz's later life and search for his pre-Welsh childhood, begins.

However, this article focuses on Austerlitz's engagement with Wales. Despite a distinguished tradition of German scholarship on matters Welsh, that location is highly unusual in modern German literature, as is the novel's use, albeit very sparing, of the Welsh language. ${ }^{3}$ As a recent commentator, Michael Maurer, has noted critically of a certain German and continental European stereotype of Wales:

Jahrhundertelang sah man in Wales eine europäische Randlandschaft, ein gebirgiges Rückzugsgebiet in Distanz zu den Metropolen und Kerngebieten nicht nur des europäischen, sondern auch des britischen Geschehens. Eine abgeschlossen lebende Bevölkerung, die sich einst bei der Besiedlung Britanniens durch Angeln und Sachsen in unwegsame, wenig fruchtbare Gebirge zurückgezogen hatte, in denen es meist regnete; eine Bevölkerung mit unverständlicher und kaum aussprechbarer keltischer Sprache, eine zurückgebliebene Randkultur, ein armes Land ${ }^{4}$

\footnotetext{
${ }^{3}$ Compare e.g. Alison E. Martin, 'Celtic Censure: Representing Wales in Eighteenth-Century Germany', Studies in Travel Writing, 18 (2014), 122-33 (p. 123).

${ }^{4}$ Michael Maurer, 'Einleitung: Wales. Die Entdeckung einer Landschaft und eines Volkes durch deutsche Reisende (1780-1860)', in Wales: Die Entdeckung einer Landschaft und
} 
Maurer considers this view to have been commonplace until the era of devolution from the late 1990s. The German adjective 'welsch' and its cognates, etymologically related to the name Wales, meaning in some contexts 'strange' or 'foreign', and connoting at times incomprehensible, inferior or deceptive language, become doubly resonant here. ${ }^{5}$

So, from some metropolitan or continental standpoints, Welsh cultures and languages have looked marginal, and Wales unassociated with the master narratives, parade-grounds and battlegrounds of modern Europe which troubled Sebald, thus seeming to map with his antiauthoritarian, peripheral intellectual inclinations. Another, related, idea of Wales offers a Romantic tradition of aesthetic response which corresponds to tropes and themes in Austerlitz. ${ }^{6}$ This resonance is exemplified in the novel's treatment of one celebrated traveller, J. M. W. Turner (1775-1851), who painted the Mawddach estuary in 1798. In line with that tradition, and the often-linked genre of travel writing, the Wales of Austerlitz offers extraordinary events and supposedly ancient, supernatural narratives. ${ }^{7}$ One example of the former is the drowning of Emyr's childhood home, the village of Llanwddyn in rural mid-Wales, to form Lake Vyrnwy. The latter is represented in the ghost stories told to Jacques/Dafydd in Bala by Evan the shoemaker, who claims to have second sight. $^{8}$

eines Volkes durch deutsche Reisende (1780-1860), ed. by Michael Maurer (Frankfurt am Main: Peter Lang, 2014), pp. 7-22 (p. 7).

${ }^{5}$ I thank Markus Klinge for this observation.

${ }^{6}$ Compare e.g. Footsteps of Liberty and Revolt: Essays on Wales and the French Revolution, ed. by Mary-Ann Constantine and Dafydd Johnston (Cardiff: University of Wales Press, 2013); Wales and the Romantic Imagination, ed. by Damian Walford Davies and Lynda Pratt (Cardiff: University of Wales Press, 2007); Shawna Lichtenwalner, Claiming Cambria: Invoking the Welsh in the Romantic Era (Newark: University of Delaware Press, 2008); Writing Wales, from the Renaissance to Romanticism, ed. by Stewart Mottram and Sarah Prescott (Farnham and Burlinton, VT: Ashgate, 2012).

${ }^{7}$ Compare 'Teithwyr Ewropeaidd i Gymru / European Travellers to Wales', http://etw.bangor.ac.uk/ (accessed 6 September 2017).

${ }^{8}$ Compare e.g. Studies in Travel Writing 18 (no 2) (2014). 
However, the Elias home is a place of material and emotional deprivation and Austerlitz's Wales no idyll. In this, too, it is characteristic of Sebald's wider oeuvre. Jessica Dubow and Richard Steadman-Jones argue that 1940s-50s Wales encapsulates Sebald's interests as they can be reflected in language, for 'the Welsh language itself was then and is now the site of a struggle involving painful questions of identity and genealogy that speak to the dilemma of Austerlitz's biography and, indeed, to a broader condition of exile. ${ }^{9}$ Carol Tully observes that Wales in Austerlitz is an apocalyptic "place of exploitative destruction - of nature in particular, but also of society'. ${ }^{10}$ Equally Sebaldian is, conversely, Andromeda Lodge, one of what J.J. Long calls Sebald's sporadic 'sites of resistance' within the oppressive modern world. ${ }^{11}$ Such features make Austerlitz's Wales as exceptional in German literature as it is emblematic in Sebald's, and for these reasons alone it merits closer reading. This article aims therefore to enrich understandings of both Sebald's work in particular and modern German literary views of Wales in general by offering a new, close analysis of this key aspect of Austerlitz.

In so doing, this article considers too the wider implications of reading the novel from (a) different perspective(s). Mary-Ann Constantine and Dafydd Johnston write of 'a relatively common occurrence to anyone working on Welsh culture', namely the curious optic of reading about Welsh issues in texts emerging from other contexts. ${ }^{12}$ In such readings, "people and texts that seem central, canonical, mainstream in Wales appear as if viewed through the wrong end of a telescope' (p. 2) or otherwise subject to strange shifts in perception; or they may simply

\footnotetext{
${ }^{9}$ Jessica Dubow and Richard Steadman-Jones, 'Mapping Babel: Language and Exile in W. G. Sebald's Austerlitz', New German Critique, 39 (2012), 3-26 (p. 12). Further references follow in the text.

${ }^{10}$ Carol Tully, 'Out of Europe: Travel and Exile in Mid-Twentieth-Century Wales', Studies in Travel Writing, 18 (2014), 174-86 (p. 180).

11 J. J. Long, W. G. Sebald: Image, Archive, Modernity (Edinburgh: Edinburgh University Press, 2007), p. 62.

${ }^{12}$ Mary-Ann Constantine and Dafydd Johnston, 'Introduction: Writing the Revolution in Wales', in Footsteps of Liberty and Revolt, pp. 1-10 (p. 2).
} 
vanish. The same can be said of places, locations and cultures, and such effects are vivid when reading Austerlitz with detailed awareness of Welsh context. This article aims to show how productive reading with such an awareness can be; and how such reading may itself, in turn, to readers familiar with Austerlitz, render the novel in some senses strange, or 'welsch'. Put most globally then, this article is interested in the practice and rewards of non-metropolitan reading, and relationships between the supposed centres and margins of literature and ways in which they remain subject to perpetual (re-)negotiation. This focus resonates with Sebald's own interest in revalorising themes, cultures and locations sidelined by dominant narratives of history.

More specifically, this article sets out, first, to consider why the novel's rich poetic passages on Wales have often evaded the gaze of scholarship on Sebald's writing to date. Second, it comments on ways in which Austerlitz may also have seemed eccentric to Welsh critical canons. Third, this article places the novel in new intertextual relationships with the cultural history of Wales. It argues that Austerlitz simultaneously turns away from Welsh history and yet reveals it in unexpected ways which have potentially transformative significance both for an understanding of the novel, and of Sebald's poetics more broadly. Fourth, this article suggests alternative historical and critical frames in which Sebald's Wales becomes productively legible.

\section{'Here Be Dragons': Critical Responses to Sebald's Wales}

The two main Welsh sections of Austerlitz appear in its first quarter and cover some sixty-five of its 421 pages. They introduce motifs which inform the novel as a whole, albeit sometimes in near-subterranean (or sub-aquatic) ways. One example is the touch of a woman's hand on the protagonist's head, first in Bala, then at Andromeda Lodge and later, a remembered or 
dreamed Prague. Another is the ambiguous image of the scriptural Deluge, seen in a decorative panel at the Great Eastern Hotel, Liverpool Street, which immediately triggers Austerlitz's impulse to tell his story, beginning in Wales. Allusion to the Deluge recurs for instance in association with the waters at Vyrnwy and Bala and the nursery at Iver Grove, a decaying English country house explored by Austerlitz in the post-war years. It is even present in 1990s Nuremberg where Austerlitz breaks his rail journey home from Prague, setting foot for the first time in Germany and overwhelmed by moving crowds which he imagines as powerful currents. This image of the flood is also associated with the novel's important trope of water in multiple forms. Moreover, it is in Bala that the novel's images of exodus and sometimes its encampments in the wilderness first appear, in Jacques/Dafydd's children's Bible. In terms of characterisation, these motivic networks illuminate Austerlitz's interior worlds; in narrative terms they underpin the novel's Uncanny poetics. ${ }^{13}$ Consequently, Austerlitz's Welsh passages form a psychological, aesthetic and symbolic matrix for the novel as a whole. To take another image from this part of the work, the dammed (damned) lake and what lies beneath, this section serves as symbolic reservoir for much of what is to come.

And yet Wales is not much foregrounded in scholarship on Sebald's work. Where aspects of this topic are discussed, for example in some studies cited here, it is commonly relatively briefly, within discussions of other, larger issues or approaches. Reasons for this circumstance are numerous, often inter-related.

First, the novel's narrative and its techniques tend to guide responses away from Wales. Austerlitz remarks that he has never felt at home anywhere, including Wales, and is more powerfully interested in his obliterated Prague childhood than his remembered Welsh one. The novel's representation of Wales, while moving, is in many ways apparently conventional. It makes use of pathetic fallacies (rain, ice and snow in Bala; sun and haze at Andromeda Lodge),

${ }^{13}$ Compare Dubow and Steadman-Jones, 'Mapping Babel', pp. 12-16. 
evocations of familiar Romantic and travellers' tropes of Wales and highly familiar, dark pictures of Nonconformist life with its chapels as "grim fortresses of an oppressive theocracy" as M. Wynn Thomas puts it. ${ }^{14}$ Such features may suggest that there is little here to attract further attention in comparison with other, seemingly more surprising aspects of the novel. Thus, the novel's early Welsh segment can recede in the reader's memory.

Second, in line with the image outlined by Maurer above, Wales itself is often marginalised in criticism originating outside specifically Welsh perspectives. As Constantine and Johnston write, Wales, to many (implicitly English-reading) eyes:

appears less foreign, and less troubling, in matters of politics and religion than do Scotland and Ireland, and is more likely to be overlooked. And yet [...] it is also more foreign in its actual text production - and so even more likely to be overlooked. Here be dragons indeed; from a critical perspective, Welsh culture is still, all too often, off the map. ${ }^{15}$

Even in recent archipelagic criticism, which explores writings of the British Isles from expressly comparative, non-Anglocentric points of view, often 'Wales has been the Cinderella nation, misrepresented and overlooked'. ${ }^{16}$ While Constantine and Johnson are discussing scholarship on Romanticism, their observation applies more generally too.

Third, scholarship on Austerlitz, on a steep upward curve of development since 2001, tends to focus on what might be called its grandest narratives and preoccupations. In Elizabeth Baer's summary, critics variously identify these major concerns as 'time, modernity, railroads,

\footnotetext{
${ }^{14}$ M. Wynn Thomas, In the Shadow of the Pulpit: Literature and Non-Conformist Wales (Cardiff: University of Wales Press, 2010), p. 19, a study which simultaneously underlines ways in which Welsh Nonconformist culture exceeds such limited images.

${ }^{15}$ Constantine and Johnston, 'Introduction', p. 3.

${ }^{16}$ Constantine and Johnston, 'Introduction', p. 2.
} 
"suppressed history", intertextuality and the creation of a new genre, the relationship of identity and exile, and disorientation, nostalgia, and Holocaust melodrama as travel writing. ${ }^{17}$ Baer suggests adding 'the following catalogue (about a novel that loves catalogues): memory, labyrinths, decay / evanescence, animals (especially birds), catalogues, photographs, journeys, the search for identity, and institutions such as museums and libraries.' This enumeration bears further expansion. Debate on such overarching topics in Austerlitz frequently takes precedence over analysis of the specific and supposedly minor. Moreover, criticism on Sebald is often comparative in that it is interested in themes and techniques which span more than one of his works. Wales, being apparently absent from those other writings, is lost to such a view.

Fourth, interpretations informed by Sebald's biography, public comments, reading or literary estate do not turn often to Wales, for he had no well-known links there. ${ }^{18}$ Neither did he work or comment extensively on writers prominently associated with Wales. ${ }^{19}$ Rather, his elucidation in interview of the Welsh connection in Austerlitz focuses on one aspect, namely a real-life model for the protagonist, Susi Bechhöfer. ${ }^{20}$ Bechhöfer, with her twin sister Lotte, was

${ }^{17}$ Elizabeth Baer, 'W. G. Sebald's Austerlitz: Adaptation as Restitution', in Reworking the German Past: Adaptations in Film, the Arts, and Popular Culture, ed. by Susan G. Figge and Jenifer K. Ward (Rochester, NY: Camden House, 2010), pp. 181-99 (p. 191). Later criticism has added to this list.

${ }^{18}$ Sebald refused a post in the Drama Department at Bangor University in 1970, because it led away from his interests. Richard Sheppard, 'The Sternheim Years: W. G. Sebald's Lehrjahre and Theatralische Sendung 1963-75', in Saturn's Moons: W. G. Sebald-A Handbook, ed. by Jo Catling and Richard Hibbitt (Oxford: Legenda, 2011), pp. 42-107 (p. 87). Sheppard's detailed 'W. G. Sebald: A Chronology' in that volume (pp. 619-58) does not mention Wales, although this account cannot be exhaustive: Sebald was likely, for instance, interviewed at Bangor.

${ }^{19}$ Sebald's personal library at the time of his death included little related reading, Jo Catling, 'A Catalogue of W. G. Sebald's Library', in Saturn's Moons, pp. 377-441. Of course he may have read further on Wales elsewhere.

${ }^{20}$ See Richard Sheppard, 'An Index to Interviews with W. G. Sebald', in Saturn's Moons, ed. by Catling and Hibbitt, pp. 592-618. Interviews mentioning Bechhöfer include 'This Distant Place: Conversation with Steve Wasserman' (2001), in Catling and Hibbitt, pp. 364-75 (p. 365); Joe Cuomo, 'A Conversation with W. G. Sebald' (2001), in the emergence of memory: Conversations with W. G. Sebald, ed. by Lynn Sharon Schwartz (New York and London: Seven Stories, 2007), pp. 93-117 (p. 111); 'St Jerome Lecture 2001: W. G. Sebald 
fostered in Cardiff under circumstances in some ways similar to Austerlitz's and in 1996, with Jeremy Josephs, published a memoir, Rosa's Child, on which Austerlitz draws. ${ }^{21}$ This solitary reference offered by Sebald to Welsh inspirations might seem at first sight fully to explain the presence of Wales in Austerlitz, thus deflecting further critical curiosity about it, as does the fact that focus on Wales in Rosa's Child is limited. Bechhöfer lived there with her foster family for some ten years, while also attending a Welsh boarding school a little longer, so that only some twenty-five pages of 159 in the whole book are set in Wales and there is no great emphasis in it on the country itself or related matters. Most significantly of course, Rosa's Child focuses on quite different issues, like its subject's search for her lost family, including her Jewish mother Rosa, murdered in the Holocaust. Critical debate on Sebald's novel and links to Bechhöfer has followed this emphasis, as well as Bechhöfer's own urgent response to Austerlitz and the ethics of Sebald's use of her life and memoir. ${ }^{22}$

Fifth, and finally, to a reading which is alive to the conscious artistry of Austerlitz, Sebald's representations of Wales may seem not to be Wales at all. This paradox is seen for instance in their evocation of Nonconformist, often scripturally-named chapels, 'the Tabernacle, Llandrillo [...] Chapel Uchaf, Gilboa [...] Chapel Bethesda, Corwen [...] Bala Chapel' (p. 74). This enumeration blends the historical ('Chapel Bethesda, Corwen', a real place of Congregationalist worship in the 1940s and 1950s, and before and after) and the apparently fictional ('Chapel Uchaf, Gilboa'), In line with Sebald's regular practice of subtly

in Conversation with Maya Jaggi and Anthea Bell' (2001), In Other Words: The Journal for Literary Translators 21 (2003), 5-18 (p. 6).

${ }^{21}$ Jeremy Josephs with Susi Bechhöfer, Rosa's Child: The True Story of One Woman's Quest for a Lost Mother and a Vanished Past (London and New York: IB Tauris, 1996). While not in Sebald's library, this work according to Martin Modlinger was known by him. "'You Can't Change Names and Feel the Same": The Kindertransport Experience of Susi Bechhöfer in W. G. Sebald's Austerlitz', in The Kindertransport to Britain 1938/39: New Perspectives, ed. by Andrea Hammel and Bea Lewkowicz, Yearbook of the Research Centre for German and Austrian Exile Studies 13 (2012) (Amsterdam: Rodopi, 2012), pp. 219-32.

${ }^{22}$ E.g. Baer defends Sebald; Modlinger is critical. 
altering real-life topographies. While numerous places in Wales bear Biblical names, a settlement of any prominence called Gilboa is not among them. ${ }^{23}$ Thus, the primary significance of Gilboa here seems symbolic. In scripture, King Saul's sons were killed and Saul fell upon his sword (1 Samuel 31: 1-4) in a battle at Mount Gilboa and King David curses it with drought (2 Samuel 1:21). This placename, a site of catastrophic violence which destroys father, sons and family continuity, echoes the themes of Austerlitz, its accursed dryness correlating with the Eliases' spiritual and emotional aridity.

Similarly, Austerlitz prioritises the aesthetic over geography in the Fitzpatrick uncles' funeral at Cutiau on the Mawddach. That experience is associated for Austerlitz with a work by Turner: not the painting 'The Estuary of the Mawddach' (1798), but more unexpectedly, 'Funeral at Lausanne' (1841). Deane Blackler writes:

Turner's watercolour, for the vigilant Sebaldian reader [...] can never now be separated from the misty autumn morning above the Mawddach [...] Who can say [...] whether the Turner watercolour of Lausanne is more or less real than the funeral at Cutiau, now that that particular watercolour is forever fused with Sebald's literary appropriation of it, calling to mind Turner's other drawings and paintings of the Mawddach valley? ${ }^{24}$

Here, Wales is not only overlaid with washes of Turner's colour. By implication, it is arguably effaced and replaced by an imagined Switzerland of a different time. Interested readers

\footnotetext{
${ }^{23}$ Such names recall enduring religious discourse on Wales as "'spiritual Israel"”, J.R. Jones, quoted in Dorian Llywelyn, Sacred Place, Chosen People: Land and National Identity in Welsh Spirituality (Cardiff: University of Wales Press, 1999), p. 112. See especially pp. 78 114. Gilboa is not a usual name for a Welsh chapel.

${ }^{24}$ Deane Blackler, Reading W. G. Sebald: Adventure and Disobedience (Rochester, NY: Camden House, 2007), p. 109.
} 
consulting maps will find no cemetery marked at the tiny hamlet Cutiau. ${ }^{25}$ The cartographic absence of a graveyard appears to confirm the fictional, intertextual character of this Wales. ${ }^{26}$ Consequently, Austerlitz's mid-century Wales can appear in principle interchangeable with any other Romantic location and time, appearing less as a locus of realist mimesis than as a conspicuously imaginative, textual space.

\section{Writing Wales and Austerlitz}

Yet to a perspective in which Wales is not marginal, the recession implied by such readings of the lived experience of a location is striking. It is possibly in part for such reasons that Sebald's work is generally absent from studies with a primary interest in Welsh writing in a conventional sense, or in the literary representation of Wales. A memorable passage of the novel describes Jacques/Dafydd's fantasies about Llanwddyn, before the village and its valley were submerged. For Jacques/Dafydd, this narrative is the 'Hauptstück' of the 'alttestamentarisch[e] Vergeltungsmythologie' (p. 78) which dominates his thinking. Supported by a handful of old photographs of Llanwddyn, he responds intensely, imagining himself at the dark bottom of the lake amongst its other unsaved inhabitants.

Austerlitz himself remarks, in a tangential way, that Vyrnwy was formed by the construction of a dam in 1888 . This statement is historically accurate, but omits the facts that this reservoir was created to supply the English city Liverpool, and not unique. Among a

${ }^{25}$ The very name Cutiau means in Welsh simply means 'sheds' or even 'hovels', seemingly underlining its modest scale and suggesting it is unlikely to have such features as a graveyard. ${ }^{26}$ Popular modern maps reveal no graveyard, e.g. AA Road Atlas Britain: Wales (Basingstoke: Automobile Association, 1987); Ordnance Survey North \& Mid-Wales / Gogledd a Chanolbarth Cymru Travel Map (Southampton: Ordnance Survey, 2007); Philip's Road Atlas Northern England and Wales (no pl.: George Philip, 1990) ('Britain's Most Detailed Road Atlas'). No cemetery appears either on the more detailed Ordnance Survey Outdoor Leisure 18 - Harlech, Porthmadog \& Bala / Y Bala (Southampton: Ordnance Survey, 2007). 
number of similar projects was the highly controversial plan of 1956-65 (when Austerlitz is still visiting Wales, or has only recently stopped doing so) to flood the Tryweryn valley and Welsh-speaking community of Capel Celyn, very near Y Bala. Those works produced Llyn Celyn, another reservoir for Liverpool, and had far-reaching political, symbolic and cultural impacts, constituting a key trope in strands of twentieth- and twenty-first century Welsh politics and discourses of identity. ${ }^{27}$ The flooding of Tryweryn survives, too, as a painful theme in contemporary Welsh literature and the critic Jane Aaron relates it centrally to a sense of a 'primary experience of violation' which in Wales 'remains alive as a central trauma in the cultural memory of a people'. ${ }^{28}$

Austerlitz makes no mention of this fraught context. Instead, Jacques/Dafydd's Vyrnwy mythology is deeply personal and idiosyncratic. That treatment reflects Austerlitz's rejection as an adult of his Welsh childhood, his inward-looking character and resistance to engaging with anything, as he recognises, that happened after the nineteenth century. Indeed, the very representation of Vyrnwy as a mysterious, haunted lake rather than a reservoir, that is, a major, hard-headed industrial project, turns away from history. Thus, the omission from Austerlitz of the broader, more obviously political discourse of the twentieth century about reservoirs, culture, language, destruction and power in rural Wales seems to set the novel apart from some canonical trends in Welsh writing.

Moreover, the Welsh language is not used where one might expect it, for example in the record Emyr keeps of his (often Welsh-language) sermons, a document which is cited in English. Elsewhere, the use of Welsh is not conventional. One of the novel's two direct uses of the language occurs when Jacques/Dafydd visits Emyr in an 'Anstalt' (p. 100) in Denbigh,

\footnotetext{
${ }^{27}$ See e.g. Philip Jenkins, A History of Modern Wales 1536-1990 (London and New York: Longman, 1992), pp. 399-400.

${ }^{28}$ Jane Aaron, Welsh Gothic (Cardiff: University of Wales Press, 2013), p. 3. Further references appear in the text.
} 
following the minister's widowhood and breakdown. A 'Wärter' says to Emyr, “'Your son's here to see you, parech"” (p. 100). “"P]arech"' here may represent the standard abbreviation of 'Parchedig' ('Reverend'), 'Parch.' ('Rev.'). ${ }^{29}$ However, the lower-case initial letter and spelling are neither standard nor evident regional variations, and the abbreviation itself is not normally used in this way as a form of address. In other words, the novel's use of Welsh, while extraordinary in modern German literature, is limited, on the face of it offering little scope for studies interested in literary uses of the language.

Sebald was not in any familiar sense a Welsh writer. Hence, although parts of Austerlitz. resonate with certain traditions in Welsh literature in English, for example its negative representations of Methodist life, connections with that kind of writing rarely feature in criticism. ${ }^{30}$ In this respect Arthur Williams's early, brief suggestion that Austerlitz can be linked to R.S. Thomas's poetry remains exceptional. ${ }^{31}$ Likewise, while Sebald has been influentially seen as a travel writer, he is not known as a visitor to Wales and does not much feature in criticism on Welsh travel writing. ${ }^{32}$ Tully's work on travel and exile writing about Wales stands out in including Austerlitz, while drawing attention to the fact that writing about travel and exile, despite potential links, do not always seem to match up in conceptual terms. ${ }^{33}$ This observation evokes the wider problem in using ideas like genre to discuss Austerlitz, which in many senses works against them: this work in general evades straightforward ways of thinking

\footnotetext{
${ }^{29}$ This abbreviation appears in the only Welsh-language book preserved in Sebald's library, Moses yr Arweinydd Mawr [Moses the Great Leader] (Wrexham: Hughes a'i Fab, 1922) by a well-known author and minister, named in it as 'Y Parch. E. Tegla Davies'.

${ }^{30}$ On such tradition, see M. Wynn Thomas, In the Shadow of the Pulpit.

${ }^{31}$ Arthur Williams, "immer weiter ostwärts und immer weiter zurück in der Zeit': Exploring the Extended Kith and Kin of W. G. Sebald's Austerlitz', in Neighbours and Strangers: Literary and Cultural Relations in Germany, Austria and Central Europe since 1989, ed. by Ian Wallace and Juliet Wigmore (Amsterdam: Rodopi, 2004), pp. 121-41 (p. 131).

${ }^{32}$ See e.g. Catling, 'Biblioteca abscondita: On W. G. Sebald's Library', in Saturn's Moons, ed. by Catling and Hibbitt, pp. 265-97 (pp. 279-81); The Undiscover'd Country: W. G. Sebald and the Poetics of Travel, ed. by Markus Zisselsberger (Rochester, NY: Camden House, 2010).

${ }^{33}$ Tully, 'Out of Europe', p. 175.
} 
about literature, including categories traditionally used to identify Welsh writing in various senses.

\section{Patterning Welsh Intertexts}

Yet as Williams indicates, Welsh intertextual references are centrally important to Austerlitz and attempts to understand their workings are revealing. For instance, they often manifest distinct patterning, as two cases demonstrate. First, Martin Modlinger has shown that Austerlitz bears many parallels to Rosa's Child. However, differences between these two works are significant too. Bechhöfer's memoir recounts years of sexual and emotional abuse by her foster father as well as her twin's severe long-term illness and early death. Neither of these terrible experiences features in Austerlitz's life, beyond briefly mentioned childhood fantasies about an invisible twin. Yet despite Bechhöfer's great suffering and losses, Rosa's Child also describes career achievements, unbroken religious faith, partial success in tracing family, reunion with living relatives, enduring marriage and motherhood. Her son, at the time of writing, had achieved educational and creative success as an adult, and connectedness to his mother's past. Bechhöfer's search for her lost family, while painful, is presented also as a source of emotional insight; its telling appears in part as self-empowerment.

At the time Austerlitz tells the narrator his story, he has survived nervous breakdown, discovered some of the truth about his past, found his loving former nanny in Prague and begun to reflect anew on his life. He has sought a new connection with the narrator, and hopes to trace his estranged friend Marie de Verneuil. In these respects, his experiences distantly echo Bechhöfer's. However, until this point in his life, he has failed to reach professional goals, maintain deep adult relationships or build a connection with past or future generations. While Austerlitz may, in telling his story, be beginning an exploration similar to Bechhöfer's, the 
novel's open ending suggests that that process is still nascent. Thus, while Bechhöfer's life involved severe trials absent from Austerlitz's, it also places more emphasis on achievement over adversity.

Second, Williams suggests intertextual association between Austerlitz's account of Jacques/Dafydd's hospital visit to Emyr and R.S. Thomas's poem 'Death of a Peasant' (1958). Both Emyr and R.S. Thomas's dying man Davies lie in bed and turn their face to the wall. ${ }^{34}$ However, this similarity is not necessarily a case of direct influence. Turning one's face to the wall and weeping is proverbial in Welsh for despair and resignation, a now little-known expression rooted in scripture. This origin may be shared by Sebald's and R.S. Thomas's references, suggestive of a community and language permeated with Biblical imagery due to Nonconformist tradition. In Isaiah 38: 1-3, King Hezekiah of Judah is sick and, anticipating death, turns his head to the wall and weeps. But both Sebald and R.S. Thomas strip detail from that intertext. The Book of Isaiah reveals that in this extreme moment Hezekiah prays, and God grants him additional years. That redemptive prospect is absent from Emyr's end as well as Davies's. Taken together, the uses in Austerlitz of Rosa's Child and the Book of Isaiah change and darken these intertexts in apparently consistent ways, which invite further examination.

\section{The Most Notorious Parrot of the Twentieth Century: Intertextuality and History}

Furthermore, awareness of Welsh context offers a complex reading of Austerlitz's treatment of intertextuality and history, as the Cutiau episode shows. Of course, the uncles' funeral is fiction, and analyses like Blackler's rightly emphasise its artistry. Nonetheless, despite the

\footnotetext{
${ }^{34}$ R.S. Thomas, 'Death of a Peasant' (1958), in Penguin Modern Poets I: Lawrence Durrell, Elizabeth Jennings, R.S. Thomas, no ed. (Harmondsworth: Penguin, 1962), p. 98. While the parallel image is the only source Williams gives for the idea of a reference to R.S. Thomas, he describes Sebald as a valued personal interlocutor, p. 139, n. 18, so this point may also have emerged in conversation.
} 
glamour of Turner's canonical paintings and associated temptations of reading this scene solely with reference to those works, it does not point away altogether from real topography. Despite what recent maps may say, and readers infer, there are indeed a chapel and graveyard at Cutiau, now in domestic use. ${ }^{35}$ Hence there is a persistent, if muted, call in this passage to the granular detail of Wales, to history and place. Simultaneously, a locally-informed gaze facilitates more critical investigation of supposedly authoritative texts about Wales, like maps, suggesting that they can be deceptive instruments of power which pay little heed to (supposed) peripheries like the North-West Welsh coast. In this light, while the scene at Cutiau may appear to obscure historical reality in favour of fiction and intertextuality, on searching examination, it connects with that reality in near-invisible, yet important, ways.

The same may be said of other aspects of North-West Wales in Sebald's novel. Andromeda Lodge is as idyllic as it is eccentric and Austerlitz recounts that Charles Darwin, once a guest of the Fitzpatricks, called the estate 'paradiesisch' (p. 127). For the protagonist, it offered 'Frieden, der [...] ununterbrochen herrschte' (p. 119), and this peace seems to be linked in part to the absence of an economic base, for, as in the case of Vyrnwy, the novel erases capital and work from this part of North Wales. During Austerlitz's and Gerald's youth, none of the Fitzpatricks seems to be in a paid occupation and there is no mention of the fortune which must have founded and sustained the estate. Because Andromeda Lodge appears to be severed from any economic activity or wealth, it becomes a genuinely utopian, that is, impossible place, and hence doomed, like Iver Grove.

\footnotetext{
${ }^{35}$ A chapel, Capel Cutiau (but no graveyard), appears on the Ordnance Survey England and Wales 6in Scale Merionethshire (Southampton: Ordnance Survey, 1954), $3^{\text {rd }}$ edn, Sheet XXXVI NE. That chapel may therefore have been in religious use in the 1950s, when the Fitzpatrick funeral occurs. It is nonetheless unlikely that the Catholic Evelyn and atheist Alphonso, had they existed, would have been buried at a Nonconformist chapel. I thank Dan Gibson and Osian Llewelyn for their help with these reflections.
} 
This portrayal diverges starkly from that of industrial South Wales which Jacques/Dafydd visits in his ninth year. At an unnamed location in the South, he sees, in an image reminiscent of the work of an earlier traveller, George Borrow, in his journal Wild Wales (1862):

[eine] Gegend, in der die Flanken der Berge zu beiden Seiten der Straße aufgerissen waren und die Wälder zerfetzt und niedergemacht. [...] der Ort [...] in dem wir bei Einbruch der Nacht anlangten [...] war von Kohlenhalden umgeben, deren Ausläufer stellenweise bis in die Gassen hineinreichten. Als Quartier hatte man uns [...] ein Zimmer gerichtet, von dem aus man einen Förderturm sehen konnte mit einem riesigen Rad, das sich manchmal so und manchmal andersherum drehte in dem dichter werdenden Dunkel, und weiter talabwärts sah man in regelmässigen Abständen von jeweils vielleicht drei oder vier Minuten hohe Feuer- und Funkengarben aus den Schmelzöfen eines Hüttenwerks stieben bis hoch in den Himmel hinauf. (p. 77)

This view is of Hell, with its fires, mills and perpetually turning wheels of torture. Along with a deadly air-raid on a local cinema, it seems to inspire Emyr's terrifying sermon next day on ‘die Rache des Herrn, über den Krieg und die Verheerung der Wohnstätten der Menschen' (p. 78). In this contrast between Romantic North and pandemoniac South, Wales seems to be poetically restructured by extreme binary oppositions, rather than shown, as it is in reality, as a place of topographical and economic diversity and complex historical contradictions.

Yet an obscured stratum of intertextual allusion complicates such a reading. The section of Austerlitz on Andromeda Lodge includes a photograph of a man in a garden, wearing morning dress with a parrot on his shoulder, alongside two other similarly-dressed men and two alarmed-looking women in 1930s fashions (pp. 128-29). The picture's quality recalls 
newspaper photographs, and it seems important partly because it is one of only six in the novel to take up a double page. But, as is characteristic in Sebald's use of images, it has no caption, and the author does not comment on it in prominent interviews. ${ }^{36}$ Readers can therefore only guess at the photograph's significance from the text surrounding it. It appears shortly after the account of Gerald's great-grandfather who met Darwin in 1869 and invited him to Andromeda Lodge. Subsequently, this ancestor transformed the house into 'eine Art Naturhistorisches Museum' (p. 127), and sailed around the world, bringing back exotic birds, as well as importing others. Descendants of this collection live on the estate, and others are kept in death in bespoke boxes in a custom-made cupboard, in which image the novel's recurring allusions to the columbarium, in both its senses, is condensed, dream-like.

The most impressive of these preserved specimens is Jaco, an African Grey Parrot, who:

stammte aus dem Kongo und hatte [...] das hohe Alter von sechsundsechzig Jahren erreicht. Er sei [...] überaus zahm und zutraulich gewesen, habe leicht gelernt, vielerlei mit sich selbst und anderen gesprochen, ganze Lieder gepfiffen und teilwise auch komponiert, am liebsten aber die Stimmen der Kinder nachgeahmt und von diesen sich unterrichten lassen. Seine einzige Unsitte sei es gewesen, daß wenn man ihm nicht genug Aprikosenkerne und harte Nüsse zu knacken gab, [...] er mißgelaunt herumging und überall die Möbel zernagte. (p. 125)

Appearing as it does two pages later, the photograph of the man with the parrot seems to illustrate the Fitzpatricks' ancestral affinity with birds, perpetuated by Gerald who keeps carrier

${ }^{36}$ There is no allusion to Morgan in Sheppard's 'An Index to Interviews with W. G. Sebald'. 
pigeons, prefiguring his later passion for aviation. The reader may therefore speculate that the picture shows another bird-loving forefather at a party at Andromeda Lodge.

However, outside Austerlitz this image has different meanings. In Welsh history, the man with the parrot is Evan Frederic Morgan, $2^{\text {nd }}$ Viscount Tredegar (1893-1949). ${ }^{37}$ Evan Morgan was descended from the fabulously wealthy Morgan dynasty, known as the 'kings of south Wales'. ${ }^{38}$ He appears here with his pet Blue Boy around 1935, probably at one of his famed garden parties at seventeenth-century Tredegar House in Newport. ${ }^{39}$ Morgan, while gay, married twice but left no children so the family title died with him, and the family seat was soon sold due to costs and death duties, becoming a Catholic boarding school. ${ }^{40}$ Morgan suffered lifelong poor health and was both a devotee of black magic and convert to Catholicism who claimed to have studied for the priesthood and became a Chamberlain to the Pope. He did not pursue any conventional career, but as a major landowner in London's East End, stood (unsuccessfully) for Parliament there and published many literary works. Morgan was known too for his extravagance, parties, fancy dress, colourful lifestyle and self-stylisations.

This image resonates across Sebald's works. For instance, the Venetian title of one of Morgan's poetry volumes, The City of Canals, and Other Poems (1929) parallels Sebald's first

\footnotetext{
${ }^{37}$ I thank Professor A. Deri Tomos and Mrs Megan Tomos for this reference. This picture often features in publications about Morgan, albeit commonly cropped, excluding the other figures; in full it appears in e.g. Rosemary Low, A Century of Parrots (Mansfield: Insignis, 2006), p. 270, which identifies three of the other subjects as an Alderman of Newport, his wife and housekeeper. Further references follow in the text.

${ }^{38}$ William Cross and Hon. Evan Morgan, Lord Tredegar: Selected Letters, Prose and Quotations. The Mystic Muse of Evan Frederic Morgan (Newport: William P. Cross, Book Midden Publishing, 2015), p. 134, n. 16. Unless noted otherwise, references to Evan Morgan's life are from this work and Monty Dart and William Cross, Aspects of Evan: The Last Viscount Tredegar. With a Transcript of his Court Martial for Offences Against the Official Secrets Act (Newport: Book Midden, 2012).

${ }^{39}$ Morgan's life, and his family's, are much mythologised, including by Morgan himself. Cross cautions against taking anecdotes about them as truth. My discussion thus refers not to Morgan's life, but stories circulating about him.

${ }^{40}$ See Hugh Montgomery-Massingberd and Christopher Simon-Sykes, Great Houses of England and Wales (London: Laurence King, 2000), pp. 130-39.
} 
major literary prose work, and, according to Helen Finch, 'possibly the queerest of [his] texts', Schwindel. Gefühle. (1990). ${ }^{41}$ Here, protagonists visit an intertextually-inflected Venice, itself an allusion to the German literary tradition of the Italian, especially Venetian journey and its complex sexual invitations. Like Sebald's in Schwindel. Gefühle., Morgan's Venice is stamped by imagined violence and dark secrets. ${ }^{42}$ It is also, of course like Thomas Mann's, the locus of unhappy attraction which finds a correspondence in what Finch identifies as an elusive 'homoerotic longing' in Sebald's volume. ${ }^{43}$ Other poems in Morgan's collection too evoke locations shared with Schwindel. Gefühle. and equally marked by desire, like Riva and Lake Garda.

There are similarities with stories about Morgan's life in Sebald's Die Ausgewanderten (1992), not only in its interest in (sexually and/or otherwise) non-conforming men. That work's opening narrative, 'Dr Henry Selwyn', refers amongst other locations to East London's slums at the time that the Morgans owned them. More noticeably, Morgan's wealth, family position, fragile health, fantasy life and itinerant, cosmopolitan lifestyle recall his contemporary Cosmo Solomon in the tale of the emigrant 'Ambros Adelwarth'. Cosmo is the eccentric, unmarried heir of a rich New York banking family and parallels between his life and Morgan's image are remarkable, down to shared travel destinations and choice of costumes.

In Austerlitz, Morgan's presence chimes inter alia with the recurrent figure of the bachelor, read by Finch for its queer potential in Sebald's work generally; the Catholic tradition of the Fitzpatricks; the illness of uncle Evelyn; decaying mansions; educational and other institutions; the declining family line and East London where Austerlitz lives later in life,

\footnotetext{
${ }^{41}$ Helen Finch, Sebald's Bachelors: Queer Resistance and the Unconforming Life (Oxford: Legenda, 2013), p. 92.

${ }^{42}$ Evan Morgan, 'The City of Canals' in The City of Canals and Other Poems (London: Kegan Paul, Trench, Trubner \& Co, 1929), pp. 1-10.

${ }^{43}$ Finch, Sebald's Bachelors, p. 92.
} 
perhaps in a former Morgan property. ${ }^{44}$ Gerald's fascination with aviation is matched not only by Cosmo, but Morgan's first wife Lois, who flew a plane. She had a zoologist as a lover and died tragically young, so that aspects of her life too are refracted in Austerlitz.

Above all, the link between the Morgans and Austerlitz is avian. The $2^{\text {nd }}$ Viscount's mother is said to have had a bird mania, making giant nests to inhabit. While Morgan's menagerie at Tredegar House contained 'bears, gorillas and kangaroos, with whom His Lordship liked to box', above all, he is associated with birds. ${ }^{45}$ During the Second World War, Morgan was court-martialled for breaching the Official Secrets Act, in Ipswich amongst other locations, in relation to his work as Commanding Officer of the Military Intelligence Unit 'Special Section, Carrier Pigeons', which involved pigeons flying back from the Netherlands with information. This situation connects with Austerlitz and its interests in carrier pigeons, the shadow of the wartime and Nazi eras, personal fallibility, East Anglia and dangerous travel from or over the Low Countries.

Morgan kept many birds, including Blue Boy, famous for swearing and party tricks like climbing up the Viscount's trouser leg and peeping out of his fly. ${ }^{46}$ According to Rosemary Low:

Blue Boy was treated with apprehension by guests. He would often lull them into a false sense of security by snuggling up to them, and then he would bite the buttons off their shirt or jacket and break them in two. He also had a penchant for attacking the pearls on ladies' necklaces, and nipping the heads of bald men. Evan entertained widely and was a most entertaining, if sometimes alarming, host. [...] if a guest displeased him

\footnotetext{
${ }^{44}$ Cross mentions a brief reference made by Sebald to Evan Morgan, with no source, in Cross and Morgan, Lord Tredegar, p. 133.

${ }^{45}$ Montgomery-Massingberd and Simon-Sykes, Great Houses, p. 135.

${ }^{46}$ Montgomery-Massingberd and Simon-Sykes, Great Houses, p. 135.
} 
he would whisper to Blue Boy who would drop down onto the floor, go underneath the table, and nip the ankles of the offending guest. H.G. Wells was once pecked by Blue Boy, and claimed that he could never 'gratify that damned bird. ${ }^{47}$

Blue Boy is even said to have bitten Hermann Goering in Italy. Indeed, he achieved a reputation all his own amongst his kind: Low, an authority on parrots, calls Blue Boy '[o]ne of the most notorious parrots of the $20^{\text {th }}$ century'. ${ }^{48}$

By remaining unidentified in the text, the image in Austerlitz of the man and parrot preserves the motif of the quirky, upper-class, bird-loving family while depriving it of facets of the Tredegar story. The contradictory, capricious images of Evan and Lois Morgan and their stormy marriage are split into several bachelor characters, the suffering Catholic Evelyn, the naturalist Alphonso and gentle Gerald, all of whom lack the couple's reportedly less pleasant traits and conflicts and seem to live in celibacy and solitude. Even Blue Boy is transformed from an aggressive, lewd, if possibly anti-fascist bird into the amiable, cultivated and (possibly reassuringly) deceased Jaco. These transformations play into the idealised character of Andromeda Lodge which is set apart from historical reality. Indeed, paired with other ways in which the Fitzpatricks seem unusual in a Welsh context, the photograph arguably detaches Andromeda Lodge from Wales as well, for whatever a reader may see in the image of Morgan and Blue Boy, it does not tally strongly with more familiar or stereotypical images of the country. The photograph may instead evoke a geographically non-specific, more fanciful past, and figures more readily associated with a Continental Modernist aesthetic. One instance is Joris-Karl Huysmans's protagonist Jean des Esseintes in the novel À rebours (1884), the last

${ }^{47}$ Low, A Century of Parrots, p. 270.

${ }^{48}$ Low, A Century of Parrots, p. 270. 
of a rich aristocratic line, who retreats from the world and keeps a grandly embellished pet tortoise.

Nonetheless, to the eye which recognises Morgan and Blue Boy, their image uncovers a rich, hidden vein of Welsh history in Austerlitz. The photograph connects almost subliminally with the political turmoil of the Morgans' times and the oppressive sexual politics which is, in Finch's argument, their correlative. It recalls too the economic realities of the Tredegar estate which was founded on land and property, transport, coal and heavy industry, and hence the large-scale exploitation of the natural environment and people. Thus, on an evident level, Austerlitz seems to simplify and aestheticize Wales and to drain it of history, even Welshness, as that mysterious quality might be imagined, and to superimpose on it a less historically specific fantasy. But on another level, that Romantic vision is rendered difficult by the picture of the Viscount and his parrot.

\section{'Morgan [...] oder Jones': Welsh Names}

There is resonance in Austerlitz between the (unspoken) name of Evan Morgan and that of Evan the shoemaker and 'Geisterseher' (p. 82), whose second sight recalls Morgan's interest in magic. Remembering first being told of his real name, the adult Austerlitz describes bafflement: 'Wäre mein neuer Name Morgan gewesen oder Jones, dann hätte ich das beziehen können auf die Wirklichkeit.' (p. 102). Here too, Evan Morgan is evoked, especially since the names Jones and Evans are variants of one another. ${ }^{49}$ Such echoes of Evan Morgan's names draw discreet attention to the Viscount's secret role in the novel as a representative of those

\footnotetext{
${ }^{49}$ T. J. Morgan and Prys Morgan, Welsh Surnames (Cardiff: University of Wales Press,
} 1985), pp. 130-38. 
aspects of (Welsh) life which its protagonist suppresses. In addition, Jacques/Dafydd's momentary fantasy of being called Morgan or Jones makes Evan Morgan into his own alter ego or alias (Elias). ${ }^{50}$ At the same time, this thought suggests a wish to make Evan the shoemaker, and by extension, Evan Morgan, into a powerful, alternative father figure.

Dubow and Steadman-Jones note that in Sebald's work:

Coincidence $[\ldots]$ seems to be the very thing that marks history with the signature of the uncanny, that unsettling phenomenon which disturbs all security of order and sense by slipping the boundaries of what is inside and outside, habitual and unknown [...] it is easy to forget that the book's coincidences are the result of artifice. (pp. 14-15)

In Austerlitz, coincidence between names is a key example of that technique. In a Parisian cemetery, Austerlitz reflects on the graves of a Jewish family called Hirsch, the last generation of which falls victim to the Holocaust. He is put in mind of a woman whom he once knew named Amélie Cerf, for her French surname seems to be a translation of Hirsch and so to suggest she may have been a Hirsch descendant. Thus, the echoing of names even across centuries and languages alerts the reader to an otherwise occluded past and its legacies. Read in this light, the partially veiled repetition in Austerlitz of the names Evan and Morgan participates in Sebald's poetics of coincidence which bears uncanny witness to a repressed, traumatic (personal, sexual, political, economic) history.

Emyr's name is powerfully allusive too. His surname Elias reminds readers of the prophet Elijah, associated with punitive drought visited on a sinful society like that at Gilboa (1 Kings 17: 1). Moreover, Emyr shares a name and biographical traits with a North Welsh

${ }^{50}$ Baer highlights the Elias/alias resonance, p. 194. 
Methodist 'Prince among Preachers', John Elias (1791-1841). ${ }^{51}$ Like Emyr, John Elias gave famous sermons which left crowds 'in fear and trembling' and was linked with Y Bala, a centre for Calvinistic Methodism. ${ }^{52}$ John Elias also, like Emyr, was an authoritarian paterfamilias who suffered dreadfully in the composition of his sermons and was 'reputed never to smile'. ${ }^{53}$ Interestingly, John Elias changed his name as a young adult, for he was originally John Jones. As the scholar D. Ben Rees summarises a frequently-told story, at the meeting where twentyyear-old John Jones was accepted as a preacher in 1774, an older fellow minister, John Jones of Edern, asked:

\begin{abstract}
'What is the name of this young man?' The answer was given, John Jones. Then the preacher asked 'What is the name of his father?' An answer came, Elias Jones. 'With all due respect,' said the Reverend John Jones, 'call the boy John Elias, or otherwise we will all be John Joneses. ${ }^{54}$
\end{abstract}

As well as being a pragmatic move, John Jones/Elias's change of name had religious relevance, for as R. Tudur Jones concludes: 'And so it may be said that in conformity with apostolic precedent John Elias was given his new name on the day when he was commissioned to preach the Gospel. ${ }^{55}$

This narrative reflects the fact that in Wales, in the modern period, a relatively small number of surnames, like Jones, has been very common. As one figure, himself called Jones,

\footnotetext{
${ }^{51}$ R. Tudur Jones, John Elias: Prince among Preachers (Bryntirion, Bridgend: The Evangelical Library of Wales, 1975). Further references appear in the text. Information about John Elias is taken from this work as well as those in the references below.

${ }^{52}$ D. Ben Rees, John Elias and the Calvinistic Methodists, 1791-1841 (Llangoed, Anglesey: Tŷ Rhys Chapel, 2007), p. 13.

${ }^{53} \mathrm{M}$. Wynn Thomas, p. 35. There are also further parallels between the two men.

${ }^{54}$ Rees, John Elias, p. 6.

${ }^{55}$ Rees, John Elias, p. 5.
} 
in Borrow's Wild Wales remarks: 'there [are] very few real surnames in Wales.' 56 '[R]eal surnames' here are presumably English-style surnames with diverse origins, rather than common patronymics like Jones (or Evans, or Morgan). Such names are derived from the older Welsh custom, in some parts continued into the nineteenth century, of taking one's father's first name as a surname, so that surnames regularly changed between generations. It is to this practice that John Jones of Edern suggested the younger John Jones revert. ${ }^{57}$

Such names may not seem to be 'real surnames' either because they recall times when surnames were not fixed in the family line, so the value judgement Borrow's speaker implies is telling about the intimate relationships between patrilinearity, identity, politics, power, margin and centre. The custom of changing surname with each generation was gradually given up in Wales with social and economic change and the concomitant advance not only of Anglicisation but a modern bourgeois outlook. Such developments are mirrored in the way John Elias immediately made his old/new surname permanent, for his own son was also called John Elias. Thus, John Elias senior seems to stand for a historical moment where the patrilinear surname and the conventionally legible, modern social order associated with it become more firmly established.

The sub-textual presence in Austerlitz of John Elias thus underpins Emyr's story with a sense of historical authenticity, spiritual conformity and bourgeois family values. At the same time, this parallel is presented in a critical light. While John Elias's death was mourned by a crowd of 10,000 including his children, childless Emyr in his final years is unable to preach, ill and alone. ${ }^{58}$ Thus, while Emyr stands for an authoritarian culture associated with the name

\footnotetext{
${ }^{56}$ George Borrow, Wild Wales: Its People, Language and Scenery (1862) (London and Glasgow: Collins, 1955), p. 95.

${ }^{57}$ Compare Morgan and Morgan. John Jones/Elias's mother, Jane Josephs, was the daughter of Joseph Roberts, and his father, Elias Jones, the son of John Cadwaladr, whose first name thus had only just given rise to the newly-established family surname Jones.

${ }^{58}$ Rees, John Elias, p. 22.
} 
Elias, he fails to uphold that tradition and in the last analysis, like Gwendolyn, is broken by it. Likewise, the alienating imposition of the name Elias on young Jacques illustrates that culture's dark side. By contrast, while Austerlitz, like John Elias, reverts to an original family name in young adulthood, this surname is his unmarried mother's, and so unlinked to frightening paternal authority. His father Maximilian lives easily in a family which is not cemented by marriage and does not share his name and so deviates from the patriarchal values apparently represented by the Elias name.

On a thematic level, then, in the case of the surname Elias, local knowledge enhances a reading of Austerlitz, for readers unfamiliar with Welsh Nonconformist tradition may not recognise the wide field of allusion which this name evokes. Here, it points to the rich, complex history of Methodism in Y Bala and social change in Welsh modernity, albeit in their negative aspects only, as well as a critique of modern family values associated with fathers and their names. On a stylistic level, such use in Austerlitz of recurrent Welsh names seems, in Dubow's and Steadman-Jones's words, to bear 'the signature of the uncanny' in a characteristically Sebaldian way.

Yet simultaneously, the Welsh context causes interference with such a classic reading of the literary technique of coincidence. As the anecdote about John Jones/Elias above suggests, some names in Wales, like Evans and Jones, are so widely shared that coincidences between them are more the rule than the fascinating exception they might appear to be in Paris. Confirming John Jones of Edern's observation of many John Joneses in the community, another influential figure in John Elias's early ministry was a further namesake, the Reverend John Jones of Bodynolwyn. ${ }^{59}$ Furthermore, the index to an edition of John Elias's memoir and other writings lists three John Joneses, not counting John Jones/Elias himself, and twenty more

${ }^{59}$ Rees, John Elias, p. 7. 
individuals of that surname. ${ }^{60}$ In addition, the memoir refers briefly to numerous further people called Jones but not featured in its Index. So in the context of a community in which it is normal for many unrelated people to share a surname, the literary effect of usually extraordinary coincidences between names is changed and perhaps challenged. Thus, not only does Austerlitz place Wales in a new perspective; Wales, in turn, makes an apparently familiar Sebaldian aesthetic strange too.

\section{'Dark lakes with shameful secrets': Some Conclusions}

This article shows that Wales in Austerlitz occupies a liminal position in scholarship. It does not attract the particular attention of scholars on Sebald or of German or world literature, and this circumstance is telling about the marginal position of Wales in many critical perspectives. Yet the novel can evade the lens of scholarship on Welsh literatures too, for it seems not to meet conventional expectations of such writing either, due in part to the curious (half)light it casts on familiar Welsh prospects, creating strange forms, shadows and optics. This distanciation effect speaks to the power of literary language to transform and make strange.

The argument here is that to relate Austerlitz to Welsh writing is to link it productively to new critical contexts. To do so both expands those contexts and in turn illuminates or uncovers hidden references in the novel itself, as well as helping to elucidate Sebald's complex uses of intertextuality and coincidence. Examples of critical directions which bear further investigation with regard to Austerlitz are its links to travel and exile writing on Wales, its

\footnotetext{
${ }^{60}$ Edward Morgan, John Elias: Life, Letters and Essays (Edinburgh and London: The Banner of Truth Trust, 1973).
} 
intertextual relationships with Welsh literatures and to Romanticism in Wales or, in more contemporary mood, Damian Walford Davies's cartographic literary explorations. ${ }^{61}$

One approach which offers particularly compelling avenues into Austerlitz with its hauntings, mysterious bodies of water, empty houses and closed-up rooms is Welsh Gothic as elaborated by Aaron. In that enquiry, she tracks the cultural memory of Welsh reservoirs and the force involved in making them across the work of authors like Ruth Bidgood, R.S. Thomas and Caradog Prichard. Aaron writes of the ways in which 'the spectre of Cwm Tryweryn' can manifest itself in indirect form in Welsh writing, ${ }^{62}$ for example in Prichard's celebrated novel Un Nos Ola Leuad (1961) [One Moonlit Night], translated into German in 2000 as In einer mondhellen Nacht. ${ }^{63}$ Interestingly, the cover design of In einer mondhellen Nacht, featuring an arresting old photograph of two boys, is almost uncannily reminiscent of those of both Rosa's Child and Austerlitz. Moreover, that novel shares intriguing features with Austerlitz, including the North Wales (psychiatric) Hospital in Dinbych (Denbigh), recently derelict but a by-word for fear, shame and horror for some in the area during long stretches of the twentieth century. So in representing 'Dinbych', as the institution itself was metonymically called in Wales, Austerlitz maps with local and literary tradition.

Aaron comments of Un Nos Ola Leuad that '[d]ark lakes with shameful secrets lying below their desolate waters play an important role in Prichard's novel,' oblique evidence of the distressing, multivalent power of the trope of the flooded village in Welsh literature. ${ }^{64}$ This kind of Welsh Gothic writing joins hands, almost imperceptibly, with Sebald's representation

\footnotetext{
${ }^{61}$ Damian Walford Davies, Cartographies of Culture: New Geographies of Welsh Writing in English (Cardiff: University of Wales Press, 2012).

${ }^{62}$ Aaron, Welsh Gothic, p. 112.

${ }^{63}$ Caradog Prichard, Un Nos Ola Leuad (1961) (Talybont: Y Lolfa, 2008), trans. as Full Moon by Menna Gallie (London: Hodder \& Stoughton, 1973); One Moonlit Night, trans. by Philip Mitchell (London; Penguin, 1999); In einer mondhellen Nacht, trans. by Christel Dormagen (Munich and Zurich: Piper, 1999).

${ }^{64}$ Aaron, Welsh Gothic, p. 112.
} 
of drowned Llanwddyn and the neo-Gothic tower at Lake Vyrnwy, a shadowy photograph of which appears in Austerlitz (p. 325); and perhaps with Evan Morgan's occult inclinations too. Thus, the notion of Welsh Gothic brings together works which are not normally linked; and raises some of the submerged historical and political subtexts of Austerlitz's brooding lake to the surface. In this way, Welsh critical frames offer new, perhaps transformative ways of reading Austerlitz. ${ }^{65}$

Mererid Puw Davies is Senior Lecturer in German at UCL and the author of The Tale of Bluebeard in German Literature from the Eighteenth Century to the Present (Oxford: Oxford University Press, 2001) and Writing and the West German Protest Movements: The Textual Revolution (London: Institute for Modern Language Research, 2016). She has published widely on modern German literature and culture.

${ }^{65}$ This makes a larger case, too, for the value of multi-perspectival, non-metropolitan readings of literary works. 